\title{
Āta-kōrero: Building evaluative conversation
}

\section{Toni Rewiri, Veraneeca Taiepa, and Rosemary Dewerse}

At Te Whare Wānanga o Wairaka/Unitec Institute of Technology, located in Auckland, our partnership agreement, Te Noho Kotahitanga, is inspiring us to apply kaupapa Māori to strengthen our ability in evaluative conversation, in response to an external review. Āta-kōrero, an evaluative frame drawn from the work of Taina Whakaatere Pohatu in Âta, is being applied and developed via action research. Āta-kōrero is a five-step process that moves from the gathering of evidence (Āta-haere), through its consideration (Āta-titiro) and interpretation (Āta-whakaaro), to goal setting (Āta-tohutohu) and reporting (Āta-tuhi). Āta requires that this be done with great carefulness, deliberation, and thorough-going reflection, prioritising people. An initial pilot and two full implementation rounds with 65 teams delivering more than 80 programmes have been conducted since March 2019. Āta-kōrero is enabling evaluative conversation that is culturally responsive, collectively owned, increasingly rigorous, empowering, and aligned with expressed values.

\section{Hai Timata: Introduction}

In October 2018, Te Whare Wānanga o Wairaka/Unitec Institute of Technology (hereafter, Unitec) went through an external evaluation 
review conducted by its accrediting body, the NewZealand Qualifications Authority (NZQA). Unitec received "Not Yet Confident" in both educational performance and capability in self-assessment, becoming a Category 3 institution with a number of sanctions placed upon it. Key to Unitec's response has been Te Noho Kotahitanga, Unitec's partnership agreement based on Te Tiriti o Waitangi, encouraging the application of kaupapa Māori. In particular, the work of Taina Whakaatere Pohatu applying Āta to systems in social practice has inspired a means for improving capability in evaluative conversation among programme teams. Āta-kōrero, a frame for evaluative conversation, applies the priorities of Āta to: the gathering of evidence (Āta-haere); its consideration (Āta-titiro); interpretation (Āta-whakaaro); goal setting (Āta-tohutohu); and reporting (Āta-tuhi). An initial pilot and then two full rounds of implementation with programme teams across the institution is informing growth through continuing improvement, by way of action research, of evaluative conversation that is culturally responsive, collectively owned, increasingly rigorous, empowering, and aligned with expressed values.

\section{External Evaluation and Review}

Tertiary educational institutions accredited for programme delivery by NZQA regularly experience external evaluation and review. Typically, this occurs once every 4 years, but in 2018 Unitec was informed it would receive a review 2 years after the previous one, conducted in 2016. This was because of concerns NZQA held about the quality of educational practice in the institution, impacted in part by structural and management changes and ongoing financial challenges (NZQA, 2019; Unitec, 2018).

NZQA reviewers visited the campus in October 2018. Their report, published in April 2019, declared that they were "Not Yet Confident" in Unitec's educational performance and its capability in 
self-assessment - the two key areas NZQA considers. The institution moved from a Category 2 rating to a Category 3 rating (Gerritsen, 2019). Sanctions were placed upon it, impacting its ability to enrol students and develop new programmes, curtailing off-shore delivery, and requiring a Category 1 or 2 institution to premoderate and verify assessment results (NZQA, n.d.1). Unitec could also expect another external evaluation and review (EER) within 12 to 24 months.

\section{Te Noho Kotahitanga: A foundation for renewal}

In June 2019 the interim chief executive, Merran Davis, and the executive leadership team launched a renewal strategy, Te Manaakitia Te Rito. In focus was institutional support for improving educational performance, particularly the success of students, as committed to in the Mãori Success Strategy 2018-2022, and strategies developed in 2019 for Pacific, Under 25, and International student success. Key to Te Manaakitia Te Rito was Unitec's partnership agreement, Te Noho Kotahitanga, whose five principles were owned as the institution's values: Rangatiratanga (Authority and Responsibility); Wakaritenga (Legitimacy); Kaitiakitanga (Guardianship); Mahi Kotahitanga (Co-operation); and Ngākau Māhaki (Respect).

Te Noho Kotahitanga emerged from work begun in the early 1990s when statistics for Māori achievement and participation at Unitec were low. Invited by the directors to address the situation, the Pae Arahi, Haare Williams, and Hare Paniora gathered committed Māori and Pākehā staff to craft and implement The Participation Plan. The Participation Plan focused on pragmatics-advertising, enrolments, programmes, budget, and resources. Particular successes included commitment to supporting professional development opportunities for all Māori staff and a fast-growing community of Māori students. More than pragmatic co-operation was needed, however, and so the next step was to draft a partnership agreement based on 
Te Tiriti o Waitangi, committing to respecting the "equal standing which it confers on Māori and Pākehā” (Unitec, 2020). Te Noho Kotahitanga was signed at Orakei Marae in 2001 by the then CEO Dr John Webster, Council Chair John Robb, and Kaumātua Sir John Turei, and witnessed for Ngāti Whātua by Sir Hugh Kawharu. Te Noho Kotahitanga was the first such recognition of Te Tiriti by a tertiary institution (Scoop, 2007). Te Noho Kotahitanga, exemplifying partnership born from relationships of mutual respect, is important for us; it obligates and empowers (Panapa, 2015). ${ }^{1}$

As educational performance was being addressed, drawing from this foundation, internal analysis of our capability in self-assessment exposed a key gap in regard to it.

In the wake of the visit of the NZQA review panel, analysis of approximately 100 mid-year programme evaluation reports-key documents informing their categorisation-was conducted. It was discovered that reports were typically being written by programme leaders apart from their teams, creating a lack of both collective skill in evaluation and ownership of successes, issues, and goals. They were also largely descriptive and evidence was not consistently drawn upon to document effective feedback loops informing programme improvement. Interviews with 35 academic leaders and support staff across Unitec raised "the question of how best to enable programmes ... to evaluate $\ldots$ in ways that promote open and robust conversation in the context of relationship" (Dewerse, 2018). Essentially, the principles of Te Noho Kotahitanga, established for Māori advancement, but intended also to inform institutional advancement, were not clearly in evidence: Rangatiratanga, Wakaritenga, Kaitiakitanga, and Ngākau Māhaki in a context of Mahi Kotahitanga. The question became how best to realise their potential for our improvement.

1 Panapa offers a very useful critical discussion of the challenges and opportunities for Unitec in the light of the first Mäori Success Strategy. 


\section{$\bar{A} t a$}

At this point, we realised that the work of Taina Whakaatere Pohatu in promoting Āta could simply, but significantly, help us.

Pohatu (Ngāti Porou) is a kaumātua vastly experienced in the creation of kaupapa Māori frameworks and ngā take pū-"principled positionings and practice" (Pohatu, n.d.). He is respected for his work in developing and promoting the potential of Âta as a way of returning relationships and the person to the heart of systems in social practice. Äta - gentle consideration, reflective carefulness, and intentional prioritising of the whole person-ensures transformative potential, wellbeing, and advancement (Pohatu, 2004; Smith, 1997).

$\bar{A} t a$ is an embodied practice, an application, a process. In every situation, it is about being conscious, being fully present. In a seminal article Pohatu wrote in 2004 titled Ata: Growing Respectful Relationships, it becomes clear that Âta, when lent to verbs, places a weight of relational care upon them. Fundamental to Āta are practices of critical reflection and analysis, commitment to wellbeing as a holistic approach, awareness of historical context, and whanaungatanga. Inherently, it is mindful of the past and the present in purposing a better future. All evidence to hand informs wise response. Âta is gentle yet rigorous, respectful, and reciprocal. It takes time, effort, energy, and a commitment to critical analysis. It requires discipline and seeks transformation by way of careful planning and strategising. "A willingness to use this process requires a special discipline of critical reflection and when applied to any context, creates its own uniquely fashioned signposts" (Pohatu, 2004, p. 5). With some adaptation of the English, principles undergirding Āta, for Pohatu, include: Kia tōtika — aspiring to standards of quality; Kia tika tonu-acting respectfully and responsibly; Kia pai—being considerate and deliberate; Kia rangatira te mahi-mindful of the uniqueness of actions and people; Kia tūpato-careful of the consequences (Pohatu, 2004, p. 7). 
As Kimoro Taiepa, a kaihautū at Unitec who has been mentored by Pohatu, explains:

In social work you have very sensitive relationships that you have to engage in. Systemically social welfare practices weren't conducive to respectful relationships. Āta was a kaupapa Māori approach to engaging positively with others.

Āta when applied practically means to be very considerate, reflective, responsive to the situation, to the person, to the relationship. It denotes care, which thereafter draws on respectfulness, and deliberation ... to consider all perspectives of a situation or a kaupapa. (Interview recorded for an Āta-kōrero facilitator training video, 4 November 2019)

In education, Pohatu's teaching on Âta has been applied to pedagogical practice (Forsyth, 2006, 2017), but we are not aware of it being applied as a means for building evaluative conversation to satisfy external educational review.

\section{Āta-kōrero}

We began by identifying the key actions required within the evaluative process when a programme teaching team comes together to review a semester or a year. This is a key moment because the purpose of student engagement is the achieving of a qualification. Institutional reputations - and student numbers - rise or fall on the quality of programmes.

In our context, what we need to evaluate our programmes on is predetermined by the six key evaluation questions (KEQs) informed by the Tertiary Evaluation Indicators that NZQA operates. These ask us to critically analyse and set goals in: student achievement; the value of our outcomes for key stakeholders, including students; the effectiveness of programme design in matching stakeholder need; our support and the involvement of students in their learning; the 
effectiveness of governance and management; and the management of compliance accountabilities (NZQA, n.d.2, 2017).

Âta offers us means and principles for approaching these questions. First, there is the need to prepare oneself carefully, gathering evidence from a range of quantitative and qualitative sources that speak of the present mindful of past actions. Once gathered, the evidence needs to be viewed and absorbed, its relationships, trends, and gaps noticed. From there we move into interpretation of the discoveries we are making - their whys and wherefores — which informs the setting of goals for continuing improvement. Writing up the whole in a way that meets expectations for evaluative review is the final task in a process that, necessarily, repeats itself over time.

Pohatu lists a number of verbs, providing a definition for them when Āta is applied as a prefix. We drew from this list to name the five key actions for evaluative conversation.

The first action is Āta-haere. In Pohatu's definition it means to: "Be intentional and approach reflectively. Be deliberate and move with respect and integrity. This signals the act of moving with an awareness of relationships, their environments and requirements" (Pohatu, 2004 , p. 5). As Toni remembers, her grandfather would say to her as a young woman driving long distances from home to university, "Āta haere-go carefully, go safely along the roads." She thought it was a directive, until she checked with him and discovered that he wanted her to be thinking about her whole environment and its impact on her driving. We note that it can be all-absorbing to teach one class or to find our attention in a semester focused on one aspect or issue within that; programme evaluation requires awareness that the one is part of a whole, and presumes the recording of fact to inform that. Quantitative and qualitative evidence informs that whole-of-environment relational view; preparation for evaluation demands their collection and collation en route to an evaluative conversation empowering 
voice. Once the conversation is arrived at, however, Âta-haere also reminds us to approach it and our colleagues carefully.

The second key action is Āta-titiro. Pohatu defines this as: "To look and study kaupapa and their many relationships, with reflective deliberation" (Pohatu, 2004, p. 6). Veraneeca, as a child with poor eyesight, was often told "Āta titiro". This was not just about what was directly in front of her, but about everything around, above, and below, being conscious of what she was seeing, hearing, and thinking, and understanding that her thoughts would also play a role in how she would respond in her behaviour. Already the integration in mātauranga Māori is evident. These key actions are not linear steps but spiralling activities. Looking over one's evidence traverses a landscape of place and time. Noticing and reading the patterns, the insights, and the anomalies our evidence offers inspires the questions necessary for generating analytical discussion of strengths and weaknesses.

Āta-whakaaro is "to think with deliberation, considering possibilities. It allows space for creativity, openness and reflection. The consequence is that action is undertaken to the best of one's ability" (Pohatu, 2004, p. 6). In Āta-whakaaro we are focused in our thinking, present and intentional about the kaupapa in front of us as we critically engage with our questions, probe our understanding, and employ our imagination for the purpose of opening up the way ahead.

Clarity in accountability comes in setting goals. At Unitec we have asked over time that they be SMART_-specific, measurable, achievable, relevant, and timebound (Doran, 1981). We chose Pohatu's term Āta-tohutohu. He defines and explains it as: "To deliberately instruct, monitor and correct. Grounded knowledge is a constant and valued companion. Cultural markers such as kaitiakitanga come forward to guide when appropriate, how it should be formed, applied and why" (Pohatu, 2004, p. 6). There is a tension in the combination of these two words for Māori-intention with a directive. Pohatu, in putting 
tohutohu with Âta is using the word in the sense that what has been identified must be done. Coming to it as a community makes it more urgent. Our goal setting needs to be a collaborative work that is honest and honouring, grounded in reality, yet, guided, is bold enough to bring thoughtful change.

The fifth key action in the evaluative process is Âta-tuhi. Pohatu's definition says it all: "To communicate and write with deliberation. The need to be constantly reflective; to know for what reason, writing is being undertaken. The significance of consistently monitoring and measuring quality is implicit." Reporting that exemplifies Âta-tuhi should be valuable for a team's ongoing deliberations in improvement, and for those who review them.

Te Urikore Biddle, then a kaihautū at Unitec, was the key kaitiaki of these words emerging. They were then gathered into an overall whole, which we chose to call "Āta-kōrero: Evaluative conversation". Simon Tries, Manager of Te Korowai Kahurangi: Academic Quality, was adamant that we had to return to evaluation as a collective exercise in programme teams; not a task for leaders, but core to our educational culture. Figure 1 was created following Te Urikore gaining the approval of Te Reo Advisory Committee, who laid Āta-kōrero on the foundation of the five values of Te Noho Kotahitanga. ${ }^{2}$ The koru at the centre reminds us that the key actions and the values are nonlinear, spiralling within a given iteration of the process, and over time. The weave represents the coming together of voices.

2 Members of this committee included Veraneeca Taiepa, Toni Rewiri, Hōhepa Renata, Kiri Neho, Curtis Bristowe, Lyndelle Paniora, and Matua Hare Paniora. 


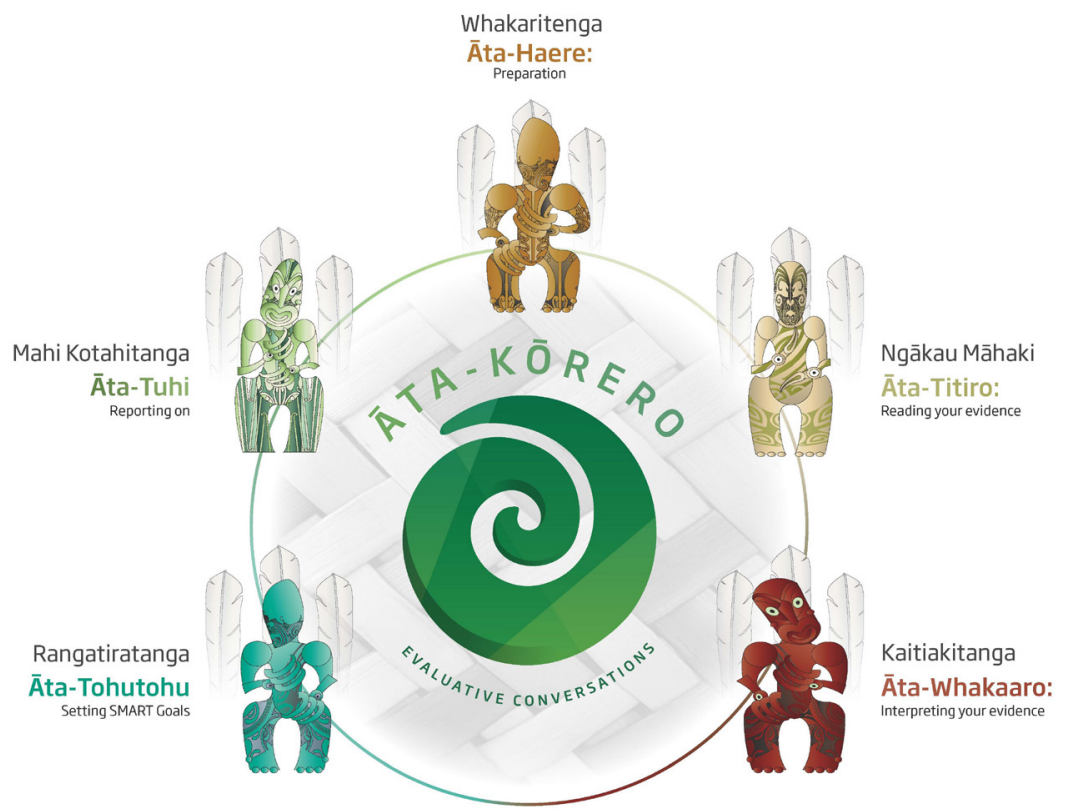

Figure 1: Āta-kōrero: Evaluative Conversation, Unitec/Te Whare Wānanga o Wairaka. Symbols of the five principles of Te Noho Kotahitanga, drawn by Hōhepa Renata

\section{Me äta kōrero tāua: Implementing Āta-kōrero}

As of June 2020, Āta-kōrero, after an initial pilot, has been applied twice at Unitec. Each iteration has been planned, delivered, and evaluated via reflection and analysis, with ever widening circles of input and participation - a work of organisational action research $(\mathrm{McNiff}$ \& Whitehead, 2000).

Three kaihautū-Te Urikore Biddle, Toni, and Veraneeca-and pouhuritao Curtis Bristowe led the launch of Āta-kōrero in March 2019, introducing the kaupapa to 60 gathered academic leaders. Rosemary, from Te Korowai Kahurangi: Academic Quality, who would be the lead facilitator, then detailed the practical aspects of our 
request to pilot it with one nominated programme per school. ${ }^{3}$ The pilot asked teams to gather for a 2-hour workshop. Another meeting later the same week repeated the introduction to a further 30 leaders. In total, they represented around $80 \%$ of programmes offered at Unitec, and included all the heads of schools.

\section{The pilot}

The pilot worked with 15 programmes across nine of the 11 schools, involving 157 staff. Additionally, 21 academic leaders sought support in evaluative writing. Typically, preparation for each workshop involved the facilitators spending 1 to 2 hours drawing from a range of qualitative and quantitative data. The workshops were run to a fairly consistent format. They began with a karakia timatanga speaking of the five principles of Te Noho Kotahitanga, an explanation of Āta-kōrero and the rules for engagement, and an invitation for all staff present to each share one good news story about the programme from the year. If names had not already been learned during arrival, they were noted at this point for use across the workshop. Then followed a mirror moment in which Rosemary and a co-facilitating colleague asked the evaluative questions the programme's evidence had raised for them and teams were given significant time to engage with the KEQs written on butcher's paper. Two concluding items followed: an evaluation of the workshop experience and karakia whakamutunga (Dewerse, April 2019).

In delivery, we discovered one key challenge and one key commitment for beginning to enculturate Āta-kōero. The challenge was that widespread understanding of Te Noho Kotahitanga, foundational at Unitec for Āta-kōrero, was not something that could be assumed. Explanation of it was often needed to ensure the process was not encountered as an unnatural imposition. The commitment, tested

3 At that stage there were eleven schools gathered generally around related disciplines. 
and seen to be of value, was the decision to ask staff to share one good news story each, in turn, before questioning and analysis began. This was a deliberate means for extending manakitanga by recognising the rangatiratanga (authority and responsibility, and leadership) of those in the room-kaitiaki (guardians) of knowledge and of students entrusted to them. In all of Rosemary's experience this has been crucial for affirming wakaritenga (legitimacy of voice) and encouraging active participation.

The main success of the pilot was in beginning to encourage team involvement in programme evaluation-Mahi Kotahitanga (co-operation) _ and, as one leader put it, in "humanising the process ... signalling its growing significance in the self-reflective process" (provided as verbal feedback). Feedback sought from workshop participants, who wrote their responses down anonymously, described the experience as "interactive", "engaging", "inclusive”, "clear", "practical”, and "informative". We also received constructive suggestions in regard to data documentation, training in reflective practice, the writing of SMART goals, and the timing of evaluative reporting. We discovered that we could not assume skill in evaluative teaching practice, and our institutional- and programme-level methods for collecting and presenting quantitative and qualitative evidence needed strengthening.

The conclusion was that Āta-kōrero was worth pursuing. The decision was made by the Quality Alignment Board to implement it across all programme teams for the 2019 mid-year programme evaluations.

\section{The first full implementation}

Sixty-five programme teams representing more than 80 programmes on offer at Unitec participated in Āta-kōrero over 4 weeks. ${ }^{4}$ Ātakōrero were facilitated by a person not belonging to a programme team to free members up to be fully present in conversation. There

4 In the intervening time, a number of programmes were marked for closure, hence the drop from 100 reports analysed in 2018. 
was time to offer potential facilitators one-off training but, for those who attended-very few of whom had experienced Āta-kōrero in the pilot-it quickly became clear that talking about the process was not nearly as effective as engaging in it. Āta is, after all, a disposition, an embodied practice; Āta-kōrero is an application of that to evaluative conversation on a specific kaupapa. Asking probing questions drawn from available evidence to ensure evaluative response, while facilitating with confidence from within a kaupapa Māori frame, was a huge expectation. Rosemary, after the 15 Āta-kōrero of the pilot, was herself still deepening her understanding and practice.

The same workshop layout was used, though a key change was that an electronic template-replacing the butcher's paper-was filled out live on-screen by an external-to-the-team notetaker, providing agreed material for the first draft for the final report. Meanwhile, reporting analysts worked hard to provide effective data on successful course completion, student and graduate survey results to the teams. The efforts to improve data provision were recorded with gratitude in a number of academic committee meetings.

In the wake of the wider mandated implementation of Āta-kōrero, much positive feedback was received, privately and publicly, about the power of the process for gathering teams together and empowering voice. As one head of school wrote: "We really appreciated the open and collaborative approach." A faculty member of 25 years' experience at Unitec, including in academic leadership, left the workshop saying, "I think this has been the most enjoyable programme evaluation I've ever experienced." Relayed via a leader, a teacher admitted coming with dread to the workshop and leaving feeling affirmed and glad to have participated. Meanwhile, an academic programme manager "really appreciated the introduction around how Te Noho Kotahitanga fits into the process and the karakia. We need to do more of this" (received by email). 
At the same time, a lot of constructive feedback was offered that sent us back into reflection upon Āta-kōrero itself. This time "us" included a further five facilitators and a few senior staff who loaned their experience and evaluative insight. Foremost was the realisation that the workshops generally were operating Āta and Te Noho Kotahitanga implicitly beyond the opening introduction of the frame. NZQA is interested in explicit realisation of stated values; therein lies integrity. How to infuse our collective kōrero and our reporting (tuhi) with the language of our partnership, truly understood, so that it becomes explicit?

From another angle, our work is not yet truly exemplifying Āta-haere and Āta-titiro in particular, to ensure Āta-whakaaro, $\bar{A}$ ta-tohutohu, and therefore Āta-tuhi. A number of the academic programme managers, responding to an emailed request for feedback, were disappointed with the quality of their team's körero, specifically because people did not come prepared with evidence to contribute. Shallow kōrero, or poor notetaking, provided little material for evaluative reporting. All this revealed that Āta-kōrero is not just a process that occurs within the confines of a workshop, but gathers in work done before, and after (Dewerse, 2019).

\section{The second full implementation}

Āta-kōrero was again conducted for the 2019 end-of-year programme evaluations across 8 weeks over summer, with all programme teams participating.

Mindful of the need to train more facilitators to spread the facilitation load, and of the need to help each one understand and embody Āta for themselves, a short course was designed and delivered beforehand. Hosted on Moodle, it taught Āta, Te Noho Kotahitanga, and Āta-kōrero via multimedia resources with participants asked reflective questions inviting them to begin operating these lenses. A kanohi-kite-kanohi workshop introduced NZQA priorities, began training in 
evidence analysis, and reflected upon the various mātauranga informing the process. From there the 12 trainees, through observation and/ or co-facilitation, were introduced to facilitating Āta-kōrero before taking the lead, with conversational self-evaluation with a colleague occurring afterward.

To address the concerns around participant preparation, a short PowerPoint video explaining the why, what, and how of Āta-haere and Āta-titiro was created, and time invested in developing dashboards providing live data, survey results, and reporting on use of student services such as extra tutoring and careers guidance. Tutorials on using the latter were offered. Relevant documentation such as course evaluations, moderation reports, and professional body feedback, was gathered into one space online for each programme for ease of reference. Meanwhile, the decision was made to require the notetaker to come from within the team as an investment toward building internal capability in evaluative writing, report-writing workshops were offered, and a guide for review of reports was created for the programme governance committees required to do this before submission.

To strengthen evaluative discussion, an additional ingredient was added by facilitators during the Āta-kōrero session. Previously left to report writers to conclude, programme teams were asked, using an NZQA rubric, to rate their performance in the six KEQS as Excellent, Good, Marginal, or Poor and use their evidence to justify this. This usefully highlighted two ongoing issues.

First, a handful of teams engaging in Āta-kōrero since the pilot, and building evaluative conversation into their ongoing life, noticeably evidenced improving cohesion and quality of evidence-based evaluative discussion on NZQA's six KEQs. However, "we discovered that not all teams regularly meet and thus have a culture of evaluative conversation" and many "did not come well-prepared for 
evaluation" despite the resources on offer (Dewerse, 2020). We did discover that few had licences to access the dashboards-a situation rectified by May 2020, at which time training workshops on how to access and investigate the data were offered and taken up by programme teams. There remains a gap in understanding of the necessity of an evaluative culture for the educational enterprise, and not just for regulatory purposes.

Secondly, the juxtaposition of the rubric alongside Te Noho Kotahitanga in the context of Āta-kōrero meant we as facilitators often struggled to bridge the tension of a worldview valuing objective judgement with a worldview valuing wholistic development. More often than not, the focus went onto the former, especially given justifying ratings in the six KEQs shaped much of the discussion. The five values-Rangatiratanga, Wakaritenga, Kaitiakitanga, Mahi Kotahitanga, and Ngākau Māhaki-were evidenced implicitly but there is still work needed to encourage their explicit inclusion. Professional development being required of all staff across Unitec in Living Te Noho Kotahitanga may change this in future. What was encouraging was positive engagement from some Māori staff appreciative of the more explicit grounding of programme evaluation in kaupapa Māori. A young lecturer wove te reo Māori and English when engaging in her workshop and afterward thanked Rosemary for her fluency in mātauranga Māori that had made her feel comfortable to be fully herself in discussion. Looking ahead, the Quality Alignment Board has agreed to investigate the possibility of employing kaupapa Māori for setting the discussion questions and criteria.

A continuing challenge in this process is building congruence between quality in Âta-kōrero and quality in the last element of the frame-Āta-tuhi. The reports that were produced from this round were analysed by a team and, employing NZQA's Rubric for Capability in Self-Assessment, around two-thirds were judged in need 
of improvement to be Good. Listening for evaluative conversation, noting it, and translating into effective critical commentary is a particular skill requiring investment and development.

\section{Te wero me te kaha: Challenges and potential}

As programme teams at Unitec prepare for another period of evaluation, "Āta-kōrero" is making its way into the vocabulary of the institution. Alongside programme evaluation, it has also been applied to cross-team work around the International Code of Practice and to programme review. The ongoing challenge, however, as noted, is that it be understood. More than that, that Te Noho Kotahitanga, the partnership agreement on which it is built, is understood and genuinely lived so that kaupapa Māori naturally integrate into our collective landscape. If so, kaupapa can then provide a natural invitation to processes that improve quality by raising up people because mauri ora (wellbeing) is so central to life (Pohatu, 2011).

In the midst of this, a further challenge for Āta-kōrero is that faculty in the tertiary sector are not required to undergo training in education as a condition of their employment. Of first interest is specialisation in a particular field. Thus, experience in evaluative practice, crucial in the training and work of primary and secondary teachers, cannot be assumed. The five actions of Āta-kōrero may belong therefore for many lecturers not just to a foreign worldview but also a foreign discipline. Each skill needs teaching, absorbing, practising, and reviewing.

Āta-kōrero is one way "Te Ao Māori is normalised, accepted and embraced 'I see me'," to quote from the Unitec Mãori Success Strategy 2018-2022. In bringing the principles and values of Te Noho Kotahitanga off the wall and into everyday life through frameworks like this and workshops that have been created, people can see that it is relevant in anything they do. In that way, kaupapa Māori benefits Māori, and also benefits all. Āta-kōrero is offering this potential for 
us. As a means for approaching evaluative conversation it also holds potential for others where partnership with Māori, and seeking to realise Te Tiriti, is a foundational commitment. Essentially, wherever people and relationships need returning to the centre of evaluative practice, Āta and Āta-kōrero offer a way for this to be realised.

\section{Te Kapinga: Conclusion}

In drawing from the work of Taina Pohatu in Āta to develop a process frame for evaluative conversation called Āta-kōrero, Unitec is discovering a way to build evaluative conversation more aligned to our values as expressed in our partnership agreement, Te Noho Kotahitanga. Developing through iterations of action research, Ātakōrero is empowering collective ownership and individual voice, even as it is revealing areas for continuing improvement in our evaluative practice. This embodied practice invites us to become increasingly rigorous in meeting the expectations of our accrediting body, NZQA, while not losing sight of the fact that people and relationships lie at the heart of our work.

As Âta has contributed to returning relationships and the whole person to the heart of systems in social practice, Äta-kōrero has brought this emphasis to the heart of evaluative conversation integral to effective education at Unitec. Its application is relevant for all contexts of Te Tiriti-based partnership.

\section{Acknowledgements}

We acknowledge the kaitiakitanga of the Te Reo Advisory Committee, and the contribution of Te Urikore Biddle, Matua Hare Paniora, and Kimoro Taiepa to this work.

\section{Ngā tohutoru/References}

Dewerse, R. (2018). Te Korowai Kahurangi: Analysis of interim PEPs (2018).

Report submitted to the Quality Alignment Board, Unitec. 
Dewerse, R. (2019). Āta-tuhi: Te Korowai Kahurangi analysis of interim PEPs (2019). Report submitted to the Quality Alignment Board, Unitec.

Dewerse, R. (2020). Āta-tuhi: Te Korowai Kahurangi analysis of the 2019 end of year PEP process. Report submitted to the Quality Alignment Board, Unitec.

Doran, G. T. (1981). There's a S.M.A.R.T way to write management's goals and objectives. Management Review, 70(11), 35-36.

Forsyth, H. (2006). Âta: A theoretical base for best practice in teaching. [Unpublished master's thesis, Auckland University of Technology].

Forsyth, H. (2017). Âta: An indigenous knowledge based pedagogical approach to teaching. Universal Journal of Educational Research, 5(10), 1729-1735. https://doi.org/10.13189/ujer.2017.051009

Gerritsen, J. (2019, 16 May). NZQA downgrades quality rating for 'marginal' Unitec. Radio New Zealand. https://www.rnz.co.nz/news/national/389315/ nzqa-downgrades-quality-rating-for-marginal-unitec

McNiff, J., \& Whitehead, J. (2000). Action research in organisations. Routledge.

New Zealand Qualifications Authority. (n.d.1). Provider categories after external evaluation and review. https:/www.nzqa.govt.nz/providers-partners/ approval-accreditation-and-registration/provider-categories/\#heading2-5

New Zealand Qualifications Authority. (n.d.2). Key evaluation questions. https://www.nzqa.govt.nz/providers-partners/self-assessment/ make-self-assessment-happen/tools-and-resources/key-evaluation-questions/

New Zealand Qualifications Authority. (2017). Tertiary evaluation indicators. https://www.nzqa.govt.nz/assets/Providers-and-partners/Registration-andaccreditation/Self-assessment/registration-accreditation-tertiary-evaluationindicators.pdf

New Zealand Qualifications Authority. (2019, April 11). External evaluation and review report: Unitec Institute of Technology. https://www.nzqa.govt.nz/ nqfdocs/provider-reports/6004.pdf

Panapa, K. (2015). Te Noho Kotahitanga: Putting the 'critical' back in biculturalism. [Unpublished masters thesis, University of Auckland]. 
Pohatu, T. (n.d.). LinkedIn profile. https://nz.linkedin.com/in/ taina-pohatu-a6052134

Pohatu, T. (2004). Âta: Growing respectful relationships. He Pükenga Körero, $8(1), 1-8$.

Pohatu, T. (2011). Mauri-Rethinking human wellbeing. MAI Review, 3. http://www.review.mai.ac.nz/mrindex/MR/article/view/380/680.html Scoop. (2007, April 16). Unitec CEO to retire. http://www.scoop.co.nz/stories/ ED0704/S00041/unitec-ceo-to-retire.htm

Smith, G. H. (1997). The development of kaupapa Mãori theory and praxis. [Unpublished PhD thesis, University of Auckland].

Unitec. (2018). Annual report Unitec 2018: Pürongo ä-tau 2018. https://www. unitec.ac.nz/sites/default/files/public/documents/Unitec\%20Annual\%20 Report\%202018.pdf

Unitec. (2020, 13 May). Our partnership. https://www.unitec.ac.nz/maori/ who-we-are/our-partnership

\section{The authors}

Toni Rewiri (Te Whakatōhea and Ngā Puhi) is Te TaharangiDirector Māori Success at Te Whare Wānanga o Wairaka / Unitec Institute of Technology.

Email: trewiri@unitec.ac.nz

Veraneeca Taiepa (Te Arawa and Ngāti Raukawa) is Kaihautū Mātauranga Māori at Te Whare Wānanga o Wairaka / Unitec Institute of Technology.

Email: vtaiepa@unitec.ac.nz

Dr Rosemary Dewerse is Academic Quality and Capability Partner, Te Korowai Kahurangi / Academic Quality, at Te Whare Wānanga o Wairaka / Unitec Institute of Technology.

Email: rosemarydewerse@gmail.com 